\title{
Design Of Electronic Medical Record Information System At University Of Indonesia Student Health Center (PKM UI)
}

\author{
Astina Atikah Sultan \\ Public Health Study Program, Faculty of Health, University of Muhammadiyah Surakarta
}

\begin{tabular}{|c|c|}
\hline ARTICLEINFO & ABSTRACT \\
\hline Keywords: & $\begin{array}{l}\text { This thesis discusses the design of the medical record } \\
\text { information system at the University of Indonesia } \\
\text { Student Health Center (PKM UI). The purpose of this } \\
\text { thesis is to design an electronic medical record } \\
\text { information system in PKM UI that is useful to produce }\end{array}$ \\
\hline $\begin{array}{l}\text { Design of information systems, } \\
\text { information systems, electronic } \\
\text { medical records }\end{array}$ & $\begin{array}{l}\text { valid, complete, and timely information and to support } \\
\text { the improvement of patient services in PKM UI. This } \\
\text { research uses qualitative methods. And system design is } \\
\text { done using the system development life cycle (SDLC) } \\
\text { stages. The results of this study are in the form of the } \\
\text { design of electronic medical record information systems } \\
\text { in PKM UI. }\end{array}$ \\
\hline $\begin{array}{l}\text { E-mail: } \\
\text { astinasultan@gmail.com }\end{array}$ & $\begin{array}{r}\text { Copyright (C) } 2020 \text { Eduhot Journal.All rights reserved. } \\
\text { is Licensed under a Creative Commons Attribution- } \\
\text { NonCommercial 4.0 International License (CC BY-NC } \\
4.0)\end{array}$ \\
\hline
\end{tabular}

\section{INTRODUCTION}

Health service facilities that develop in Indonesia are very diverse, including hospitals, health centers, private practice doctors, medical centers, 24-hour clinics, and family doctors. According to the Law of the Republic of Indonesia No. 36 of 2009 Chapter I, Article 1, what is meant by a health service facility is a tool and/or place used to organize health service efforts, whether promotive, preventive, curative or rehabilitative carried out by the government, local government, and/or the community.[1]. Health service facilities by type of service consist of individual health services and public health services, each of which includes first, second, and third level health services [2][3]. The hospital functions to provide complete health services to the community, both curative and rehabilitative[4]. Other health facilities such as puskesmas, or what are known as primary health care facilities, have the task of providing comprehensive health services, namely promotive, preventive, curative and rehabilitative health efforts in their respective work areas.[5]. Meanwhile, private practice doctors, medical centers, and 24-hour clinics play a role in providing individual health services that provide basic and/or specialist medical services, organized by more than one type of health worker. At the university level, health services are provided by the Student Health Center (PKM). All of these health care facilities have medical records which are an important part of all services provided to patients, from the first visit to subsequent visits.[6]. Medical record is a file containing notes and documents regarding patient identity, examination results, treatment, actions and other services received by patients at health facilities, both outpatient and inpatient [7][8]. According to Permenkes No. 269/Menkes/Per/III/2008 concerning medical records, every doctor or dentist in carrying out medical practice is required to make a medical record. This medical record is made immediately and completed after the patient receives the service. Making medical records is carried out through recording and documenting the results of examinations, treatment, actions and other services provided to patients. Each entry into the medical record must be affixed with the name, time and signature of the doctor, dentist, or certain health personnel who provide direct health services. As written information about patient health care, medical records are used in the management and planning of health facilities and services, medical research and statistical activities of health services [9]. Manual medical record recording has several obstacles, including: (1) requires a lot of space and 
is limited in storage; (2) it takes a lot of time to search for patient medical record data when the patient comes; (3) unable to accommodate quickly if the data is to be analyzed; (4) prone to damage and loss due to age.

Weaknesses that exist in manual medical records can be overcome by the presence of electronic medical records. Electronic medical records have the same analogy as paper-based disability but in electronic format the data can create medical study results, increase treatment efficiency, and make communication more effective between service providers and simplify health planning management [10]. The benefits of electronic medical records can also be viewed from two aspects, namely in terms of quality and efficiency. Electronic medical records aim to maintain patient safety and improve service quality.

\section{METHOD}

This research was conducted using the Rapid Assessment Procedure (primary data collection) method through direct observation, in-depth interviews using interview guidelines, and reviewing documents related to the description of the medical record system running at PKM UI. The system design was carried out using the System Development Life Cycle (SDLC) stages with the Prototype method which resulted in the design of the Medical Record Information System Database at PKM UI. The instruments used by the researcher were interview guides, observation guidelines, recording devices, and writing instruments. Interviews were conducted by the researchers themselves using interview guidelines. Determination of the number of informants needed by researchers is determined purposively and adjusted to the rules of suitability and adequacy,

Data processing is done by using content analysis method, namely by grouping data and information that have the same characteristics. The purpose of this method is to identify problems in the current medical record system. System analysis includes feasibility studies and needs analysis. A feasibility study is conducted to determine whether the development of this system is feasible or not. Aspects that are considered in the feasibility study are as follows:

a. Technical feasibility is the availability, completeness and quality of hardware, software, and information system implementing personnel to be developed.

b. Economic feasibility is the availability of funding sources for the development, operation, and maintenance of the information system to be developed.

c. Operational feasibility is the advantages and disadvantages of the system to be developed and the quality of the information produced.

d. Organizational feasibility is the suitability of the system to be developed with the existing organizational structure, namely human resources. As well as the availability of policies supporting the implementation of the information system to be developed

Furthermore, the author analyzes the information needs of system users who utilize data to determine the output to be produced by the system, the input required by the system, the scope of the process used to process input into output, the number of users and user categories, and control over the system. The system development stage is the stage for developing the required applications, the activities carried out include making system algorithms, context diagrams, data flow diagrams (DFD), relationship diagram tables, data dictionaries and interface designs.

\section{RESULTS AND DISCUSSION}

The University of Indonesia Student Health Center (PKM UI) is a non-profit public service organization, as well as the only public service provider in the health sector at the University of Indonesia. PKM UI is tasked with providing services in the fields of promotive, preventive, curative, and rehabilitative for students, employees and the general public around the UI area. Promotive actions taken include promoting health through Facebook media, distributing health flyers, and suggesting to patients over 40 years of age to have a medical check-up. Preventive measures taken are the provision of vaccines, such as hepatitis B vaccine and health checks for new students. Meanwhile, curative measures are daily services to patients and rehabilitative activities are carried out in collaboration with specialist doctors, for example for postoperative wound care. Currently, PKM UI has two clinics located on the UI Depok campus and the UI Salemba campus. 
UI PKM Health Service Procedures

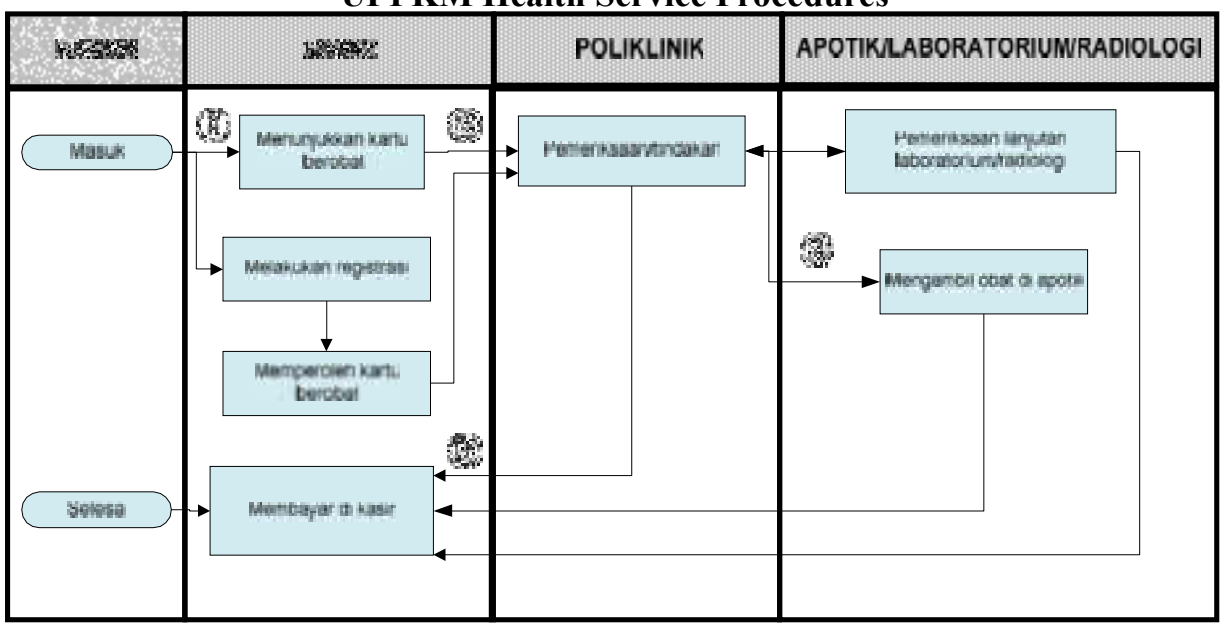

Picture. 1 PKM UI Basic Health Service Procedure

The facilities and infrastructure at PKM UI include registration rooms, waiting rooms, general poly examination rooms, dental poly examination rooms, emergency rooms, laboratories, x-rays, administration rooms and cashier rooms, pharmacy rooms and toilets. PKM UI Patient Visit Data. Medical records running at PKM UI still use a manual system, namely by using a medical record status card. There are 2 types of medical record status cards at PKM UI. The yellow one is for student patients and the green one is for employee/general patients.

\subsection{PKM UI Medical Record Information System Analysis}

In this section is a description and analysis of the medical record information system running at PKM UI. This analysis is based on the results of interviews with the person in charge of PKM UI and the service coordinator.

Description of PKM UI Medical Record Information System

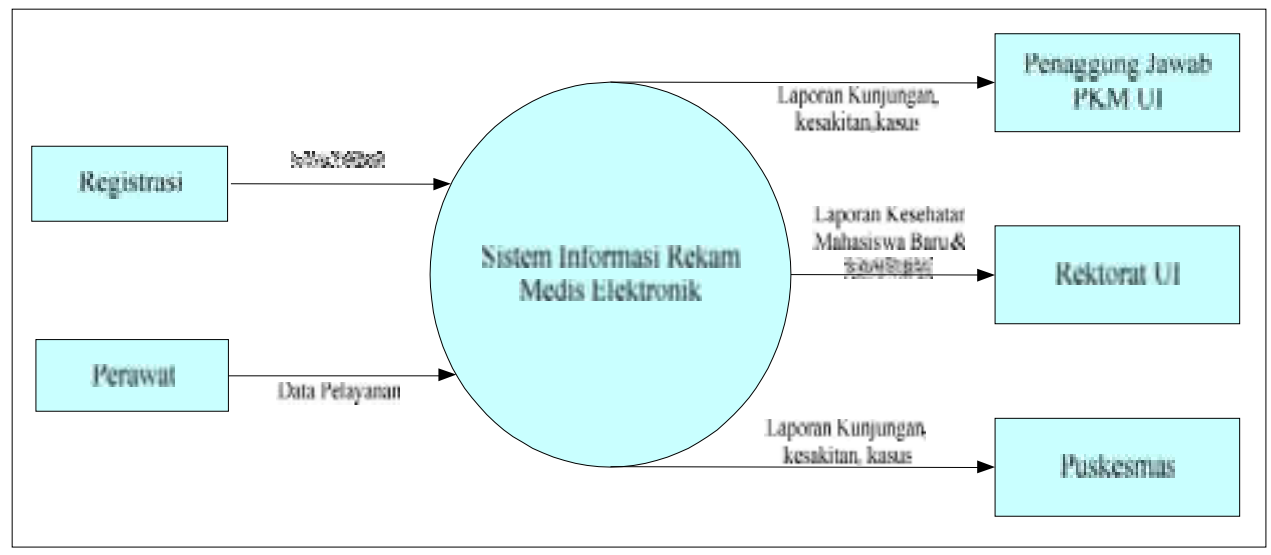

Figure 2 Context Diagram of PKM UI Medical Record Recording and Reporting

The picture above is a diagram of the context of recording and reporting medical records at PKM UI that connects the relationship between entities. Existing entities consist of source entities and destination entities. The source entity is a unit that provides data to the system, namely the registration section, doctors and nurses in each polyclinic that provides patient visit data and service data in the form of monthly reports. The service data generated is data from a copy of the nurse's record of the patient's medical record status. While the target entities are the Person in Charge of PKM UI, the Rectorate of UI, and the Beji Health Center. The three destination entities receive the same report, namely in the form of patient visit data, drug use data, and data on the use of medical devices. The following is the flow of recording and reporting the medical record system at PKM UI 


\subsection{PKM UI Medical Record Information System Input Analysis}

Input data identified include human resources, materials, methods, funds. In terms of human resources, there is no special person in charge of storing and managing medical records. This task is given in conjunction with the registrar or registration officer.

Identification of system problems is a very important stage in a research. Problems in research will determine the quality of a study, and even determine the feasibility of an activity being said to be research or not. In an effort to determine the research problem, the author has made several efforts including interviews with related parties, document review, and observation of conditions in the field. Interviews were conducted with the PKM UI Person in Charge and the Service Coordinator. Document review is done by studying the PKM UI activity report document. As for the observation, it is done by looking at the availability of facilities and infrastructure that support the implementation of the information system. Identification of problems using the input, process, output approach can be seen in the following table.

\begin{tabular}{|c|c|c|}
\hline NO & $\begin{array}{c}\text { System } \\
\text { Components }\end{array}$ & Problem \\
\hline 1 & Input & $\begin{array}{l}\text { a. There is no special officer responsible for medical records and reporting. } \\
\text { b. Not yet available base data student and patient visits at PKM } \\
\text { UI. } \\
\text { c. No process yet processing, analysis, and presentation of } \\
\text { information from the patient's medical record status. }\end{array}$ \\
\hline 2 & Process & $\begin{array}{l}\text { a. Processing, analysis, data presentation and reporting are still done } \\
\text { manually. } \\
\text { b. Data documentation on paper is vulnerable to loss. } \\
\text { c. The data search process can not be done quickly. }\end{array}$ \\
\hline 3 & Output & $\begin{array}{l}\text { a. Medical record data has not been utilized by PKM UI. The information } \\
\text { generated is general in nature. } \\
\text { b. There is no feedback mechanism for reports given by PKM UI }\end{array}$ \\
\hline
\end{tabular}

Before designing the system, the authors identify opportunities to strengthen the electronic medical record system. The identification of opportunities for developing this system is based on the analysis of interviews and observations regarding the availability of resources in the existing system and the resources needed for the system to be developed, as well as identifying the needs of system users.

\begin{tabular}{|c|c|c|c|c|}
\hline No & Element & $\begin{array}{l}\text { System which } \\
\text { exists }\end{array}$ & New system & $\begin{array}{l}\text { Development } \\
\text { Opportunities }\end{array}$ \\
\hline & $\begin{array}{l}\text { Organization } \\
\text { a. HR } \\
\text { b. Organizational } \\
\text { structure } \\
\text { c. Fund }\end{array}$ & $\begin{array}{l}\text { - Reports are made } \\
\text { by nurses in each } \\
\text { poly. } \\
\text { - Report generation } \\
\text { is done manually. }\end{array}$ & $\begin{array}{l}\text { The existence of a } \\
\text { computerized } \\
\text { system, so that the } \\
\text { data processing, } \\
\text { analysis, } \\
\text { presentation and } \\
\text { reporting can be } \\
\text { done easily. }\end{array}$ & $\begin{array}{l}\text { There is no need for } \\
\text { additional human } \\
\text { resources because the } \\
\text { new system eases the } \\
\text { burden on officers, but it } \\
\text { is necessary to increase } \\
\text { the competence of } \\
\text { officers in the field of } \\
\text { computer technology. }\end{array}$ \\
\hline & & $\begin{array}{l}\text { There is no } \\
\text { processing, analysis, } \\
\text { and presentation of } \\
\text { medical record data. }\end{array}$ & & $\begin{array}{l}\text { Special funds for system } \\
\text { maintenance. }\end{array}$ \\
\hline & $\begin{array}{l}\text { Technology } \\
\text { a. Infrastructure } \\
\text { b. Application } \\
\text { c. Communicatio }\end{array}$ & $\begin{array}{l}\text { - Availability of } \\
\text { computers in each } \\
\text { administration } \\
\text { and service room. }\end{array}$ & $\begin{array}{l}\text { - The system } \\
\text { requires } \\
\text { appropriate } \\
\text { database software }\end{array}$ & $\begin{array}{l}\text { - It is very possible to } \\
\text { implement it with the } \\
\text { availability of } \\
\text { computers and servers }\end{array}$ \\
\hline
\end{tabular}


$\mathrm{n}$ architecture

d. Development ability

Management

a. Awareness

b. Will

c. Commitments and policies
- There is already a server. and a network that can connect computers in each room.

- The system requires resources in its development

- There is an awareness of the need for good medical record data management.
- Requires awareness of the importance of a good medical record management system, so that there is a will to improve it.

- There is also a need for a commitment to carry out such improvement efforts and a binding policy for its implementation. at PKM UI.

- The next thing to pay attention to is future development.

- The system can answer existing needs, but it is necessary to pay attention to the commitment in running the system for optimal results.

The aspects tested in the feasibility study are technical feasibility, economic feasibility, operational feasibility, and organizational feasibility. These four aspects can be explained through the results of interviews, observations and document reviews. Technical feasibility includes the availability of special technologies that meet user needs in operating the new system to be implemented. In other words, this system requires a set of computers that are used to enter, process, and analyze data, and store data.

Economic feasibility includes the ability of PKM UI to provide various needs for the running of the new system which includes the procurement of computer equipment and system development if one day it is needed. Given that PKM UI already has sufficient computer equipment, there is no need to spend funds to purchase a computer. However, PKM UI still has to allocate funds for system development. Operational feasibility looks at whether the system can operate after use. Operational feasibility is highly dependent on the human resources who will operate it. Therefore, it is very important to pay attention to whether the new system is user friendly so that it is easy to understand and operate by human resources. Organizational feasibility includes PKM UI commitments and policies to be able to implement information systems.

\subsection{Discussion}

The input data used by PKM UI as well as in the design of the information system does not only come from patient data, visit data, and service data but can also come from accident data around the University of Indonesia. The resulting output can be in the form of service coverage at PKM UI, so that PKM UI knows what percentage of students/employees have used the services at PKM UI. In addition, the resulting output can also be in the form of the susceptibility/seriousness of the patient's illness based on evidence based. Suggestions for further research are to design developments for drug systems and cashier payments. Designing a database that can present the patient's disease symptoms,

\section{CONCLUSION}

The University of Indonesia Student Health Center still uses a paper-based manual medical record system. The obstacles faced so far in the implementation of manual medical records are the 
amount of time used in searching for medical record files, one patient has two medical record numbers. There is no process of processing data into information on the status of the patient's medical record, which is also a problem in the running medical record system. This Electronic Medical Record Information System is expected to be able to solve the problems that have been mentioned. With the semi-automation of this system, it is hoped that the information reported will be valid and the time required will be more efficient. The output produced is in the form of visit reports, referral reports, disease trend reports using the ICD X code in student/employee/general patients per month or per year. The resulting output is in the form of tables and graphs. Interfaces designed in the Electronic Medical Record Information System can function for database processing. The system design is made in accordance with 4 principles in system design, namely ethical, purposeful, pragmatic, and elegant so that the use of this application can be more easily understood by users. In addition, this application is also very possible to generate information from data that has been in the past. The system design is made in accordance with 4 principles in system design, namely ethical, purposeful, pragmatic, and elegant so that the use of this application can be more easily understood by users. In addition, this application is also very possible to generate information from data that has been in the past. The system design is made in accordance with 4 principles in system design, namely ethical, purposeful, pragmatic, and elegant so that the use of this application can be more easily understood by users. In addition, this application is also very possible to generate information from data that has been in the past.

\section{REFERENCES}

[1] M. Wahidin, S. Nuraini, and A. I. Thomas, "Kesiapan Fasilitas Pelayanan Kesehatan Indonesia Dalam Perdagangan Bebas Masyarakat Ekonomi ASEAN,” Bul. Penelit. Sist. Kesehat., vol. 22, no. 2, 2019, doi: 10.22435/hsr.v22i2.965.

[2] Y.- Suraja, "PENGELOLAAN REKAM MEDIS PADA FASILITAS PELAYANAN KESEHATAN," $J$. Adm. dan Kesekretarisan, vol. 4, no. 1, 2019.

[3] A. Ramadhanu, Guslendra, R. H. Arsyah, H. Syahputra, and V. Okta, "Sistem Informasi Pelayanan Kesehatan dan Rekam Medis pada Klinik Dirmiati Palapa Menggunakan Visual Basic dan MySQL," $J$. Intra-Tech, vol. 3, no. 1, 2019.

[4] A. D. Hendriani and E. N. Hadi, "EVALUASI STANDAR PROMOSI KESEHATAN RUMAH SAKIT DI RUMAH SAKIT UMUM DAERAH dr. SOEKARDJO KOTA TASIKMALAYA," Jukema (Jurnal Kesehat. Masy. Aceh), vol. 6, no. 1, 2020, doi: 10.37598/jukema.v6i1.798.

[5] F. Rabbaniyah and M. Nadjib, "Analisis Sosial Ekonomi dalam Pemanfaatan Fasilitas Kesehatan untuk Berobat Jalan di Provinsi Jawa Barat: Analisis Data Susenas Tahun 2017," Media Kesehat. Masy. Indones., vol. 15, no. 1, 2019, doi: 10.30597/mkmi.v15i1.5888.

[6] M. Husni and D. M. Putra, "Analisis Implementasi Sistem Informasi Manajemen Rumah Sakit (SIMRS) Pada Unit Kerja Rekam Medis Di Rsu'aisyiah Padang,” J. Kesehat. Lentera 'Aisyiyah, vol. 2, no. 1, 2019.

[7] M. Khasanah, "Tantangan Penerapan Rekam Medis Elektronik Untuk Instansi Kesehatan," J. Sainstech Politek. Indonusa Surakarta, vol. 7, no. 2, 2020.

[8] A. D. Arimbi, S. J. Swari, N. Nuraini, I. Muflihatin, and G. Alfiansyah, "Analisis Faktor Kinerja Pengisian Dokumen Rekam Medis Rawat Inap Klinik Dr. M. Suherman Jember," J-REMI J. Rekam Med. Dan Inf. Kesehat., vol. 1, no. 2, 2020.

[9] F. A. Istikomah, F. Erawantini, and D. S. H. Putra, "Tinjauan Pelepasan Informasi Rekam Medis Berdasarkan Aspek Hukum Keamanan dan Kerahasiaan Rekam Medis untuk Pendidikan di RSUD Sleman,” J-REMI J. Rekam Med. dan Inf. Kesehat., vol. 1, no. 4, 2020.

[10] T. G. Wati and N. Nuraini, "Analisis Kejadian Missfile Berkas Rekam Medis Rawat Jalan di Puskesmas Bangsalsari," Rekam Med. dan Inf. Kesehat., vol. 1, no. 1, 2019. 